\title{
FINANCIAL PERFORMANCE AND CORPORATE SOCIAL RESPONSIBILITY OF COMPANIES
}

\author{
DOI: 10.17261/Pressacademia.2021.1485
}

PAP- V.14-2021(11)-p.48-52

\section{Teodora-Valentina Lica}

Transilvania University, Finance Department, Brasov, Romania. teodora.lica@unitbv.ro, ORCID: 0000-0002-8951-0693

\section{To cite this document}

Lica, T.V., (2021). Financial performance and corporate social responsibility of companies. PressAcademia Procedia (PAP), $14,48-52$. Permanent link to this document: $h$ ttp://doi.org/10.17261/Pressacademia.2021.1485

Copyright: Published by PressAcademia and limited licensed re-use rights only.

\section{ABSTRACT}

Purpose- This paper aims to show how corporate social responsibility has gained importance in the world of economic societies. Case study: Romania. To this end, we will test the relationship between corporate social responsibility (CSR) and financial performance using the return on assets indicator (ROA).

Methodology- The article will focus on the analysis of the policies and projects listed on the web pages of the active companies listed at the Bucharest Stock Exchange (BVB) and that have been involved in corporate social responsibility activities during 2017, 2018 and 2019.

Findings- In our study a negative correlation coefficient was obtained ( $r=-0.19151)$ and we therefore have an inverse correlation, the two correlated variables varying in the opposite direction (when one increases, the other decreases).

The value $r=-0.19151 €[-0.2 ; 0]$ and represents a very weak correlation, almost non-existent.

Conclusion- The present paper aimed to investigate the relationship between the financial performance of companies listed in Romania on the stock exchange and the score obtained in the projects implemented by them in terms of corporate social responsibility. The very weak correlation between the two indices may mean that we should investigate more in order to obtain data that provides us with important information.

Keywords: Corporate social responsibility, return on assets, financial performance.

JEL Codes: M14; G40; L25

\section{INTRODUCTION}

Is there a connection between the world of values and the world of numbers from the point of view of companies? This paper aims to analyse the existence or non-existence of a link between financial performance and corporate social responsibility. Nowadays, there is a growing trend concerning the environment, employees, community, etc. Are more profitable the companies that are not socially involved? Is there a contrast between business ethics and profitability? An efficient use of resources can also be considered an ethical value.

Within a company, financial management is responsible for obtaining and using finance in order to achieve the proposed objectives and maximize its market value. In 1991, Carroll A. stated that CSR includes the economic, legal, ethical and discretionary expectations that society has at a given time towards organizations.

\section{LITERATURE REVIEW}

This paper aims to show how corporate social responsibility has gained importance in the world of economic societies. To this end, we will test the relationship between corporate social responsibility and financial performance.

Milton Friedman said that "the basic mission of any business is to profitably produce goods and services, and in doing so the business makes its maximum contribution to society and is in fact socially responsible."

In 2002, Bogdan I, the main author of the "Bank financial management treaty" defines financial management as being "a subsystem of the general management of the company, aiming to ensure the necessary financial resources, their allocation and profitable distribution, increase the value of the company and the security of its patrimony". In 1985, Ullmann A. explains that there are so many variables involved between financial performance and corporate social responsibility that we should not expect a relationship to exist.In another view a positive relationship between the two should exist because the real costs of CSR are covered by the benefits.

In 1953, Bowen $\mathrm{H}$. conceptualized corporate social responsibility as "the obligation of business people to follow policies, make those decisions, or follow those lines of action that are desirable in terms of societal goals and values". In the same book, the author states that "business people must behave like morally responsible agents to society." 
In MEMO/02/153 from 2002, the European Commission stated that: "Corporate social responsibility is a concept by which companies integrate, on a voluntary basis, business, and social and environmental protection objectives in all their productive or commercial operations or in relations with stakeholders ".

In 2010, the International Organization for Standardization (ISO) outlined social responsibility guidelines:

"Social responsibility is the responsibility of an organization to the impact of its decisions and activities on society and the environment, through transparent and ethical behaviour that:

- contributes to sustainable development, including the health and well-being of society;

- take into account the expectations of stakeholders;

- complies with applicable laws and is in accordance with international norms; and

- is integrated throughout the organization and practiced in all its relationships. Activities include products, services and processes.

Relationships refer to the activities of the organization in its sphere of influence. "

In 2007, Munteanu V. P. affirmed that Peter Drucker stated: "In the next society, the biggest challenge for a large company - especially a multinational - will undoubtedly be its social legitimacy: its values, its mission and its vision".

In the paper "Corporate social responsibility - support for sustainable development", Munteanu V. P. stated that leadership compensation is another issue of ethics and responsibility in relation to the economy. It is often found that managers receive very high allowances, even if the organization is profitable or not.

In 2004, Capron M. said that management of social responsibility of organizations is often misperceived as a "brand management" technique due to the sensitive link between the brand image and the opinion of the society. It is, therefore, an inadmissible error to use it strictly as a communication tool. A systemic approach is imposed, step by step, by integrating the elements already known or practiced by the organization. The social responsibility of organizations is above all a way of continuous learning and improvement.

\section{DATA AND METHODOLOGY}

The research methodology is based on the analysis of public information of companies in the fields of environment, employees, and community. The environment includes policies, systems and biodiversity reports, climate change, etc. The social field is based primarily on employees, human rights, non-discrimination, health and safety at work, trade union relations, etc., while the community includes projects to improve transport, parks and playgrounds, sponsorship of various sports teams, philanthropic actions etc.

For this paper we analyzed all the companies listed on the Bucharest Stock Exchange (BVB).

In the first phase, I studied the web pages of all the 609 active companies, and then I noticed that only 29 of them met my search criteria and were therefor included in this study. Four companies are from the extractive industry, fifteen are from the manufacturing industry, two of them are from the production and supply of electricity and heat, gas, hot water and air conditioning, two companies are from the construction field, another two from wholesale and retail; repair of motor vehicles and motorcycles, one company activates in the field of transport and storage, two in professional, scientific and technical activities, and one in the field of health and social assistance.

The 29 companies from the 8 fields of activity are listed using the symbol used at the Bucharest Stock Exchange, in the following table, depending on the field of activity.

\section{a. CSR measurement}

Based on the information published by the companies on the web pages and their sustainability reports, a score was given regarding CSR, taking into account the stated policies ( 1 point and the projects 1 point) in which they participated for the environment, community and employees. The maximum score is 6 .

Table 1: Companies listed at BVB that met our criteria, sorted by field and symbol

\section{Area of activity (CAEN)}

Extractive industry

Extractive industry

Extractive industry

Extractive industry

Manufacturing industry

Manufacturing industry

Manufacturing industry

Manufacturing industry

Manufacturing industry

Manufacturing industry

Manufacturing industry

Manufacturing industry

Manufacturing industry

Manufacturing industry

Manufacturing industry

Manufacturing industry

Manufacturing industry

\begin{tabular}{|c|c|}
\hline \multicolumn{2}{|l|}{$\underline{B V B}$} \\
\hline symbol & CSR score \\
\hline FOJE & 6 \\
\hline FOSB & 2 \\
\hline FOSP & 1 \\
\hline SNP & 4 \\
\hline ALR & 6 \\
\hline ARAX & 1 \\
\hline ATB & 6 \\
\hline BBGA & 4 \\
\hline CEON & 2 \\
\hline CMP & 4 \\
\hline ELMA & 4 \\
\hline IASX & 2 \\
\hline MABE & 2 \\
\hline ROCE & 4 \\
\hline SIDG & 3 \\
\hline SIRM & 2 \\
\hline SOPL & 2 \\
\hline
\end{tabular}


Manufacturing industry

Manufacturing industry

Production and supply of electricity and heat, gas, hot water and air conditioning

Production and supply of electricity and heat, gas, hot water and air conditioning

Construction

Construction

Wholesale and retail trade; repair of motor vehicles and motorcycles

Wholesale and retail trade; repair of motor vehicles and motorcycles

Transport and storage

Professional, scientific and technical activities

Professional, scientific and technical activities

Health and social work

Source: own investigations; www.bvb.ro

$\begin{array}{ll}\text { TRP } & 5 \\ \text { UAM } & 6 \\ \text { SNN } & 6 \\ \text { TEL } & 5 \\ \text { AUXI } & 3 \\ \text { IMP } & 4 \\ \text { ALU } & 3 \\ \text { RMAH } & 5 \\ \text { TGN } & 5 \\ \text { EL } & 2 \\ \text { SFG } & 2 \\ \text { M } & 4\end{array}$

\section{b. Measuring the financial performance of the company}

In order to measure the financial performance of the 29 companies, we will use the return on assets indicator (ROA), starting from its formula Net Income/ Total Assets $* 100$.

The return on assets shows us how much "lei" become profit by investing one "leu" in assets. The analyzed years are 2017,2018 and 2019 and the results are presented in the following table.

Table 2: Companies listed at BVB, sorted by activity field and symbol, along with the ROA indicator

\begin{tabular}{|c|c|c|c|}
\hline BVB symbol & ROA\% 2017 & ROA\% 2018 & ROA\% 2019 \\
\hline$\overline{\text { FOJE }}$ & 9,73 & 11,34 & 11,62 \\
\hline FOSB & 3,82 & 5,60 & 2,16 \\
\hline FOSP & $-7,55$ & $-13,38$ & $-20,06$ \\
\hline SNP & 5,86 & 9,06 & 7,76 \\
\hline ALR & 12,43 & 8,18 & $-7,26$ \\
\hline ARAX & $-90,36$ & 2,82 & 7,92 \\
\hline ATB & 5,88 & 4,87 & 3,89 \\
\hline BBGA & 2,62 & 14,49 & 12,46 \\
\hline CEON & 7,33 & 9,47 & 13,47 \\
\hline CMP & 6,39 & 5,26 & 4,53 \\
\hline ELMA & $-3,94$ & 1,20 & 1,10 \\
\hline IASX & 0,01 & $-10,77$ & $-8,79$ \\
\hline MABE & $-20,44$ & $-17,77$ & $-23,40$ \\
\hline ROCE & 1,78 & 1,90 & 0,15 \\
\hline SIDG & $-7,27$ & $-7,32$ & $-14,22$ \\
\hline SIRM & $-1,29$ & $-4,34$ & 0,21 \\
\hline SOPL & $-3,62$ & $-2,90$ & 2,99 \\
\hline TRP & 17,75 & 3,77 & 6,41 \\
\hline UAM & 3,53 & 1,13 & 1,05 \\
\hline SNN & 3,31 & 4,64 & 6,09 \\
\hline TEL & 0,63 & 1,75 & 2,04 \\
\hline AUXI & 3,29 & 3,82 & 189,23 \\
\hline IMP & 8,29 & 3,18 & 31,91 \\
\hline ALU & 14,59 & 0,79 & 3,55 \\
\hline RMAH & 145,99 & 175,19 & 167,52 \\
\hline TGN & $-4,84$ & $-5,37$ & $-2,84$ \\
\hline $\mathrm{EL}$ & $-175,27$ & $-110,99$ & $-26,23$ \\
\hline SFG & 182,18 & $5.818,51$ & $11.191,17$ \\
\hline $\mathrm{M}$ & 108,56 & 536,33 & 682,02 \\
\hline
\end{tabular}

Source: own investigations and calculated data; www.bvb.ro ; https://mfinante.gov.ro/apps/agenticod.html?pagina=domenii

c. $a+b$ correlation . Examining the relationship between the indicator ROA and CSR score

To examine the relationship between the average ROA for 2017-2019 and the CSR indices for the 29 companies listed on the BVB, we calculated the Pearson correlation index using the t-Test. 


\section{Table 3 : Pearson correlation index calculated using t-Test}

t-Test: Paired Two Sample for

Means

\begin{tabular}{lll}
\hline & ROA \% 2017-2019 & CSR score \\
\hline Mean & 217,5432 & 3,724138 \\
Variance & 1132399 & 2,564039 \\
Observations & 29 & 29 \\
Pearson Correlation & $-0,19151$ & \\
Hypothesized Mean Difference & 0 & \\
df & 28 & \\
t Stat & 1,081733 & \\
P(T<=t) one-tail & 0,1443 & \\
t Critical one-tail & 1,701131 & \\
$\mathrm{P}(\mathrm{T}<=\mathrm{t})$ two-tail & 0,2886 & \\
t Critical two-tail & 2,048407 & \\
Source: own investigations and calculated data
\end{tabular}

Source: own investigations and calculated data

Figure 1: Scatter graph of the correlation between the average ROA and the CSR score

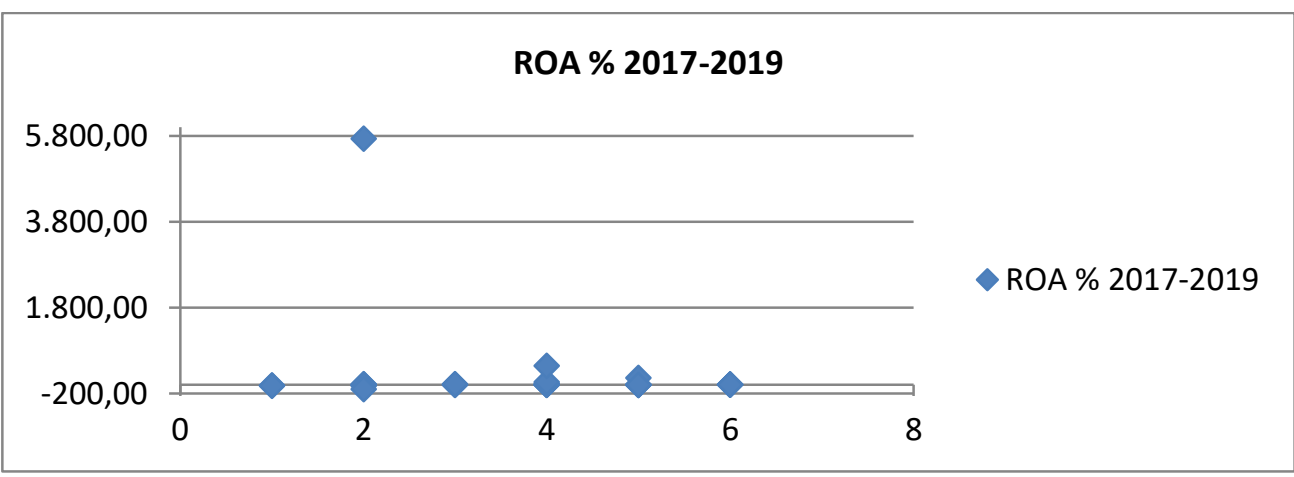

Source: own calculations

\section{FINDINGS}

Pearson's linear correlation coefficient $r$ measures the degree of connection between variables, in our case between the financial performance of the analyzed companies and the score given to them.

The correlation coefficient $r$ has values between -1 and 1 . It was calculated for the $95 \%$ confidence interval and is significant when it does not contain the value 0 , as is our case.

In our study a negative correlation coefficient was obtained $(r=-0.19151)$ and we therefore have an inverse correlation, the two correlated variables varying in the opposite direction (when one increases, the other decreases).

The value $r=-0.19151 €[-0.2 ; 0]$ and represents a very weak correlation, almost non-existent.

\section{CONCLUSION}

The present paper aimed to investigate the relationship between the financial performance of companies listed in Romania on the stock exchange and the score obtained in the projects implemented by them in terms of corporate social responsibility. The very weak correlation between the two indices may mean that we should investigate more in order to obtain data that provides us with important information.

\section{REFERENCES}

Aupperle, K. E., Carroll, A.B. \& Hatfield, J. D. (1985). An empirical examination of the relationship between corporate social responsibility and profitability. Academy of Management Journal, 446-463

Bogdan, I. (2002). Tratat de management financiar-bancar. Ed. Economica, București, 32

Bowen, H. (1953). Social Responsabilities of Businessman. New York: Harper and Row

Capron, M., Quairel-Lanoizelee F. (2004). Mythes et réalités de l'entreprise responsable, Paris: La Découverte

Carroll, A. B. (1991). The pyramid of corporate social responsibility: Tward the moral management of organizational stakeholders. Business Horizons, 34(4), 39-48. 
Friedman, M. (1970). The social responsibility of business is to increase its profits. New York Times Magazine, September 13, 32-33, 122, 126.

Munteanu V.P., Pantea I.M., Ştefea P., (2007). Integrarea responsabilităţii sociale în strategiile de afaceri ale organizatiilor româneşti, Management \& Marketing Journal, 2, 73-80.

Munteanu V., Ştefea P., Pantea I.M., (2007). Corporate social responsibility - support for sustainable development, published in Scientific Papers series I, vol. IX (2), Banat University of Agricultural Sciences and Veterinary Medicine, Agricultural Management Faculty, Agroprint Publishing House, Timişoara, 2007, ISSN 1453-1410, p.157

Ullmann, A. (1985). Data in Search of a Theory: A Critical Examination of the Relationship's among Social Performance, Social Disclosure and Economic Performance of US Firms. Academy of Management Review, 10, pp. 540-557.

https://ec.europa.eu/commission/presscorner/detail/en/MEMO $02 \quad 153$ - accessed 10 October 2021

https://www.bvb.ro/ - accessed 10 October 2021

https://www.iso.org/files/live/sites/isoorg/files/archive/pdf/en/socialresponsibility.pdf - accessed 10 October 2021

https://www.iso.org/obp/ui/\#iso:std:iso:26000:ed-1:v1:en - accessed 10 October 2021 